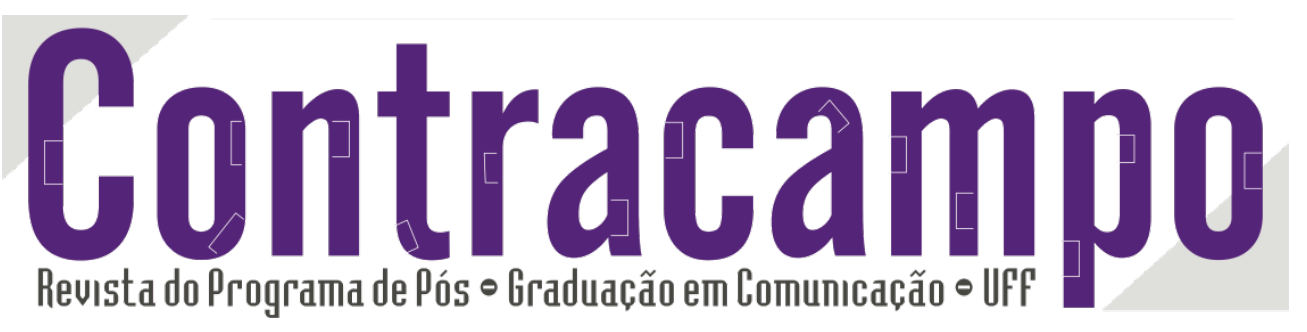

\title{
A materialidade do medo: o papel da narrativa jornalística na ampliação deste estado afetivo
}

\section{The materiality of fear: the role of the journalistic narrative in the} expansion of this affective state

\author{
Wilson Couto Borges \\ wcborges1@yahoo.com.br \\ Professor Colaborador do Programa de Pós-Graduação em Informação e Comunicação em Saúde. \\ Pesquisador em Saúde Pública na Fundação Oswaldo Cruz. Doutor em Comunicação,
}

Vânia Coutinho Quintanilha Borges

vaniacqborges@ibest.com.br

Mestranda em Comunicação e Saúde pela Fundação Oswaldo Cruz.

Possui graduação em Psicologia pela FAMATh (2003).

BORGES, Vânia Coutinho Quintanilha. BORGES,

Wilson Couto. A materialidade do medo: o papel da narrativa jornalística na ampliação deste estado afetivo.

In: Revista Contracampo, v. 26, n. 1, ed. abril, ano

2013. Niterói: Contracampo, 2013. Pags: 106-125

\section{PPGCOM}

Edição 26/2013 


\section{Resumo}

No presente artigo, estamos desenvolvendo uma reflexão que toma o medo como eixo central da conexão entre o mundo das notícias e dos leitores, ouvintes e telespectadores. O ponto de partida é a aceitação de que tal sentimento é um tipo de representação social que estabelece uma espécie de consenso entre a população, neste caso especial a do Rio de Janeiro, produzindo sentidos sobre 0 espaço urbano. Para tanto, especialmente para provocar uma aproximação entre os campos da comunicação e da psicologia, recuperaremos algumas contribuições de dois célebres autores, Mikhail Bakhtin e Lev Vygotsky, particularmente no que diz respeito à dimensão da cultura como elemento estruturante da interação social. Num segundo momento, nos deteremos sobre a questão da centralidade da cultura, destacando a luta ideológica em torno da qual se produz a construção hegemônica dos significados.

Palavras-chave: Narrativa jornalística; medo; mediação.

\section{Abstract}

In this paper, we are developing a reflection that takes the fear as a central connection between the world of news and readers, listeners and viewers. The starting point is the acceptance that such a feeling is a kind of social representation that establishes a kind of consensus among the population, in this special case of Rio de Janeiro, producing meanings of urban space. For both, especially to cause a rapprochement between the fields of communication and psychology, regain some contributions of two famous authors, Mikhail Bakhtin and Lev Vygotsky, particularly with regard to the dimension of culture as a structuring element of social interaction. Secondly, we will consider the question of the centrality of culture, highlighting the ideological struggle around which produces the hegemonic construction of meanings.

Keywords: Narrative journalism; fear; mediation. 
medo tem sido um dos sentimentos mais presentes na elaboração das informações produzidas pelos meios de comunicação massivos, especialmente no que diz respeito à produção de sentidos sobre o espaço urbano. O Rio de Janeiro tem merecido nossa atenção sistemática na última década, particularmente porque uma de nossas premissas de pesquisa tem sido o quanto a semantização sobre a formação social republicana brasileira, tendo a então capital federal como principal lócus, tendeu (e ainda hoje tende) a cristalizar determinadas visões de mundo (muito particularmente a burguesa), solapando alternativas para a construção de uma configuração mais plural, que abarcasse mais amplamente a diversidade por aqui existente. Paralelamente, já foi explorado em outra oportunidade (BORGES, 2009) o papel desempenhado pela imprensa na difusão desse ideário burguês conservador, especialmente naquilo que mostrou/ocultou no debate público pelo menos nos últimos 120 anos. Partindo desse cenário, nossa reflexão tem se desenvolvido na direção de uma investigação que tem privilegiado a sedução que as narrativas jornalísticas têm exercido sobre leitores, ouvintes e telespectadores - muito embora estejamos nos concentrando neste artigo sobre os primeiros -, a ponto de serem tomadas como verdades, a partir de efeitos de realidade muito particulares dessa forma de se contar uma história.

Um ponto que nos tem chamado a atenção é o fato de determinados sentidos conquistarem as mentes (e os corações) de determinadas formações humanas, embora esses mesmos sentidos estejam sempre sendo objeto de disputas. Tomemos a palavra medo. Trata-se de uma sensação que proporciona um permanente estado de alerta, cuja ameaça pode ser tanto física quanto psicológica. Apesar de etimologicamente estar associada ao latim metus - indicando ansiedade, temor, inquietação - percebemos que seu uso, especialmente nas páginas dos jornais, ganha uma materialidade. Nas notícias e reportagens produzidas diariamente, esse "estado afetivo suscitado pela consciência do perigo ou que, ao contrário, suscita essa consciência"; essa "ansiedade irracional ou fundamentada"; essa "apreensão em relação a (algo desagradável)" (HOUAISS, 2009, grifo nosso), ganha cor, classe social, região geográfica, longevidade. Como já havíamos mencionado, esses caracteres acompanham aqueles de quem se deve ter medo há, pelo menos, 120 anos. O que parece ter se deslocado nesse intervalo de tempo foi o "medo branco de almas negras", de Sidney Chalhoub, para o "medo urbano de almas suburbanas", na direção que tem aparecido em nossas reflexões. Nesse sentido, não nos 
parece fortuito, paralelamente, o sentido associado à palavra suburbano. Mesmo com esse adjetivo indicando: "relativo ou pertencente ao subúrbio; que ou aquele que vive em subúrbio" (Idem), parece que seu uso pejorativo: "que ou aquele que é pouco refinado, que revela mau gosto" (Idem) tem acompanhado a formação social do Brasil.

\section{O consenso como base da comunicação}

O campo da comunicação desperta o interesse de vários outros campos no que diz respeito a sua capacidade de produzir consensos em torno de determinados temas. Isso significa dizer que, apesar de olhada de fora (e às vezes de longe), em alguma medida, é relativamente comum encontrarmos trabalhos que versem sobre os dispositivos ou estratégias presentes nas construções narrativas que garantem o estatuto de verdade ao que é veiculado massivamente. Embora discordemos da maioria, particularmente pela superficialidade dos argumentos, há alguns com os quais temos sido desafiados a dialogar, seja porque imergem a comunicação num plano analítico mais profundo, seja porque ela acaba sendo objeto de escrutínio numa dimensão mais interdisciplinar. Um dos exemplos nessa direção é um grupo de pesquisadores que tem se debruçado, não diretamente sobre a mídia, mas acerca dos efeitos produzidos pela uniformidade de pensamentos, de sentimentos. A partir dessa perspectiva, julgamos que vale à pena colocar luz sobre o Procedimento de Classificações Múltiplas (PCM), utilizado por essa equipe para "analisar a organização estrutural de representações sociais do medo em adultos e o nível de consenso destas representações" (ROAZZI, FEDERICCI e CARVALHO, 2002, p. 182).

Embora o trabalho tenha como eixo principal questões metodológicas que envolvem a dimensão cognitiva dos processos de representações sociais, em particular a questão do consenso que uma representação possui para um determinado grupo social, ele nos traz um dado valioso para a problematização da nossa temática: "o medo como elementos polarizador em torno do qual se estruturam as demais representações" (Idem, p. 180). Diferentemente desses autores, nossa motivação não é identificar o nível de consenso acerca dos significados relativos à natureza da representação social, tampouco apontar esse mesmo nível dentro de determinados grupos sociais, mas realçar que "as representações sociais, por serem elaboradas na fronteira entre o psicológico e o social, 
são capazes de estabelecer conexões entre as abstrações do saber e das crenças e a concretude da vida nos processos de troca com outros" (Idem). É nesse ponto que nossos argumentos parecem se aproximar. Para eles, servindo-se de Moscovici (1961), há uma “"pressão por inferência' como consequência da necessidade que os indivíduos têm de, continuamente, reagirem à dinâmica social" (p. 361). Assim, retomando a noção de que a produção de consensos é a base da comunicação, nos interrogamos: não haveria uma estreita relação entre a pressão por inferência sobre os indivíduos (Moscovici) e a interpelação que estes agentes sofrem (Althusser) nos processos de suturação ${ }^{1}$ que os meios realizam?

Antes de avançarmos nessa relação, voltemos aos argumentos de Roazzi, Federecci e Carvalho. ${ }^{2}$ Se admitirmos que é no processo descrito acima que "emergem de forma nítida os sentidos dos processos de simbolização e da atividade cognitiva em relação aos significados que o mundo externo assume a nível da vida psíquica" (Op. cit., p. 180), duas premissas tornam-se absolutamente cristalinas: a primeira é sobre o poder que os meios desfrutam na construção de representações (carregadas de sentidos) sobre o mundo; a segunda (e concomitante a outra), sobre a influência que variáveis de ordem cultural exercem sobre as formas de apropriação do conteúdo midiático. Em nossa avaliação, tais proposições, associadas à interrogação que enunciamos no fim do parágrafo anterior, já seriam suficientes para desenvolver nosso argumento. No entanto, há uma terceira contribuição, esta com relação à interface comunicação-emoção, que gostaríamos de sublinhar. Para os autores, "ela (a emoção) prepara e modula o comportamento levando o indivíduo a agir de modo a diminuir as experiências desagradáveis e prolongar os afetos positivos" (Idem, p. 181). Ou seja, embora ainda negligenciados, os afetos, as emoções, as sensações têm um papel central na relação que

\footnotetext{
1 Sutura é um conceito apresentado por Jacques-Alain Miller num texto intitulado Suture (Elements of the logic of the signifier) e publicado originalmente no Cahiers pour l'analyse 1 (1966), mas já utilizado por Lacan para mostrar como opera a lógica do significante. A sutura consistiria numa relação entre a estrutura significante e o sujeito e, ao mesmo tempo em que assinalaria a falha, a abertura da estrutura, possibilitaria que quase não se percebesse sua presença. Nesse sentido, a sutura pode ser entendida como a interseção que se insere na própria ausência dentro da ordem simbólica sendo ela a presença-ausência da imagem que produz um efeito de realidade fantasmática, articulando significadosignificante. Advinda de uma ficção discursiva construída pelo sujeito, a narrativa jornalística ganha seu valor de verdade, pois, numa avaliação preliminar, entendemos serem elas as responsáveis por um processo de sutura entre o imaginário dos leitores e as próprias narrativas.

Doravante, estamos denominando esses autores como Grupo de Pernambuco em função das pesquisas realizadas na Universidade Federal de Pernambuco (UFPE), a partir da interface culturacognição.
} 
se estabelece entre as narrativas produzidas pelos meios e a apropriação que os atores sociais delas fazem, especialmente porque

As representações sociais, tomadas como sentido atribuído aos objetos pelos sujeitos a partir de sua prática e de suas relações (...) pressupõe que a realidade é sempre vista a partir de um recorte, uma dimensão dela mesma, nunca em si mesma. Pressupõe também que a atividade simbólica é o grande articulador deste recorte, feito a partir dos sonhos, crenças, sensações, onde emoções e afetos emergem como mediadores tão significativos quanto pensamento e linguagem, ou os processos grupais (Idem).

Ao aplicar o Procedimento de Classificações Múltiplas (PCM), a contextualização das interpretações realizadas pelos grupos pesquisados partiu, como os próprios autores destacam, do cotidiano das relações sociais em que as representações sociais são forjadas, isto é, as informações sobre homicídios, estupros, sequestros, presentes diariamente nos jornais, rádio, televisão. Assim, não nos parece acidental, por exemplo, que o medo apareça, dentro da pesquisa, associado aos perigos gerados, por exemplo, pelo desemprego. ${ }^{3}$ No panorama encontrado pelos autores, percebe-se claramente o quanto os meios de comunicação são agentes centrais no processo de construção dos sentidos socialmente partilhados:

"No grupo Violência Social temos os itens "menino de rua", "sequestro", "violência sexual", "assaltante", "desemprego", "polícia" e "acidente de trânsito". Neste a estrutura político-econômico-social vem como a "causadora" destas questões. Para a maioria desta pesquisa, o "desemprego faz com que as pessoas passem a praticar sequestros, assaltos", geralmente "são pessoas marginalizadas pela sociedade". O "desemprego" também "pode levar ao aumento do número de crianças que precisam ir para as ruas trabalhar" $e$ "acabam se envolvendo com a criminalidade"; sendo assim, ele é a "causa" evidente da marginalidade e, neste contexto, a polícia teria o papel de manter a ordem social" (Idem, p. 189, grifos nossos).

Ao destacar a força que as ideias socialmente partilhadas possuem dentro de cada sociedade, mesmo que os objetivos de pesquisa sejam qualitativamente diferentes, o Grupo de Pernambuco parece justificar a contribuição trazida de Serge Moscovici no que diz respeito à formação das representações sociais. Nesse sentido, a aproximação que propomos entre o pesquisador romeno e Louis Althusser parece particularmente valiosa para a compreensão do processo de como os meios fornecem matéria prima para que, parafraseando Moscovici (2003), uma dada formação social partilhe de um

\footnotetext{
É importante destacar que um dos procedimentos metodológicos provocados foi à associação
} livre de ideias. 
determinado conhecimento e desse modo constitua sua realidade comum, transformando ideias em práticas. Assim, não nos parece fortuito descrever que é através da ancoragem - amarrar um barco num porto seguro - e da objetivação processo pelo qual indivíduos ou grupos acoplam imagens reais, concretas e compreensíveis, retiradas de seu cotidiano, aos novos esquemas conceituais que se apresentam e com os quais têm que lidar -, que as narrativas jornalísticas constroem certo lugar onde a estrutura do significante parece não ter fissura. Dessa forma, a objetivação pode ser entendida como a atividade onde sujeitos sociais são convidados a dar sentidos àquilo que assistem, ouvem, leem. Ou, modificando-se alguns termos, seria a resposta dada ao chamamento do sujeito pelo discurso, isto é, uma resposta à interpelação que o discurso provoca. Partindo então dessa perspectiva, propomos que a interpelação promovida pelas narrativas jornalísticas não pode ser encarada como apenas mais um tipo de convocação do sujeito à atribuição de sentidos; antes, as notícias e as reportagens assumem a primazia nesse processo.

\section{A comunicação é um processo de interação e não de determinismo}

Embora a construção do nosso argumento possa conduzir o leitor à falsa noção de que leitores, ouvintes e telespectadores seriam vítimas indefesas dos meios de comunicação, nos apressamos em desfazer qualquer dúvida quanto à direção tomada. Paralelamente, não negamos o quanto contribuições trazidas do campo da psicologia têm mostrado seu vigor na análise da cena urbana. Isso parece particularmente evidente, especialmente porque, como já foi explorado em outro espaço (BORGES, 2010), há muitas conexões entre um campo e outro. Assim, quando trazemos para o debate reflexões como as produzidas (e coordenadas) por Antonio Roazzi ou Moscovici, longe de nos afastarmos dos fenômenos sociais, o que fazemos é nos aproximar ainda mais. Retomemos a questão das representações sociais, do quanto à realidade é sempre vista a partir de um recorte, de um enquadramento. Para esses pesquisadores, com os quais concordamos, a atividade simbólica é o grande articulador desse recorte. E o principal: "tal recorte é feito a partir dos sonhos, crenças, sensações, onde emoções e afetos emergem como mediadores tão significativos quanto pensamento e linguagem, ou os processos grupais" (Op. cit., 181). Antes que nos detenhamos sobre a questão dos 
afetos, das emoções, das sensações, da dimensão da linguagem, associada à do pensamento, convocamos outros dois autores, linguistas, a participarem desse debate: Lev Vygotsky e Mikhail Bakhtin.

No primeiro semestre deste ano, fomos apresentados à Lev Vygotsky por Marta Kohl, que trabalha com o linguista russo a partir de uma perspectiva interacionista. $\mathrm{O}$ ponto de partida da autora são os chamados planos genéticos de desenvolvimento (filogênese, ontogênese, sociogênese e microgênese), propostos por Vygotsky, que explicariam o funcionamento psicológico do ser humano. $\mathrm{O}$ primeiro plano representaria a história da espécie humana, definidora de limites e possibilidades de funcionamento do cérebro a partir do ambiente. Já o segundo, estaria ligado à história do indivíduo da espécie, isto é, em cada espécie, o ser percorre certo caminho de desenvolvimento, o que confere singularidade ao sujeito. $\mathrm{O}$ seguinte, o da sociogênese, seria o da história cultural do meio onde o indivíduo vive, onde ele está inserido, ou seja, são as formas de funcionamento da cultura interferindo no psicológico, definindo o funcionamento do psicológico. Por último, a microgênese, representaria o micro fenômeno, é a passagem entre o não saber e o saber: "é a porta aberta para o não determinismo", como adverte Kohl. O que tal estrutura em última instância permite é que a relação do homem com o mundo seja mediada (mediação simbólica), através de instrumentos e signos - estes, incorporados pelo sistema psicológico, mediam a partir deste sistema, inaugurando a possibilidade de representação mental.

O desenho do quadro teórico-metodológico acima permite ao pesquisador compreender como é possível ao ser humano, a partir da mediação simbólica, transitar num mundo apenas simbólico e antecipar coisas a partir de experiências de outros. Ou seja, como grande parte da ação humana é fruto das experiências de outros sujeitos, elas se tornam experiências de natureza simbólica. Ora, ainda que o foco do interesse de Vygotsky seja a compreensão do desenvolvimento intelectual, que ocorre especialmente a partir das interações sociais e das condições de vida, percebemos a presença de dois conceitos fundamentais de Bakhtin (dialogismo e polifonia), particularmente na assertiva de que o desenvolvimento humano se dá de fora para dentro e que está atrelado à cultura. Em nossa avaliação, parece haver uma estreita relação do dialogismo bakhtiniano com linguagem que está dentro do sujeito nos termos vygotskyanos; e a polifonia e a linguagem que circula fora do sujeito. Nesse sentido, não nos parece 
acidental o fato de ambos serem russos, linguistas, terem estudado o materialismo histórico de Marx e Engels, a história e a literatura, além do interesse pelo campo da psicologia - Bakhtin escrevera a obra Freudismo, em 1927. Ao que tudo indica, a combinação entre o materialismo, o estruturalismo e o freudismo fornecera a base para, a partir das críticas literárias e a análise do significado histórico da arte, uma troca fecunda entre ambos, especialmente em função da noção de que o desenvolvimento humano se dá de fora para dentro, ou seja, a experiência é elemento fundamental nesse cenário.

Para Bakhtin, o domínio da ideologia coincide com o domínio dos signos, isto é, todo discurso é ideológico. Já em Vygotsky, as regras (culturais) são incorporadas com a apropriação da língua, onde são apreendidos, paralelamente, determinados significados associados a ela. Os signos são construídos culturalmente. $\mathrm{O}$ ato de nomear é um ato de classificar. Como a experiência é fundamental para o processo de aprendizagem e de desenvolvimento, como ela é igualmente fruto da experiência de outros que influenciam na ação humana, nos interrogamos: em que medida, a criança, ao mimetizar o mundo adulto nas regras de funcionamento da cultura, não incorpora as regras do mundo adulto? Se a experiência do medo no adulto (e as fantasias associadas a esse sentimento) é da mesma ordem da experiência do medo na criança, como argumentam Roazzi, Federicci e Carvalho, não estaríamos diante de um cenário onde o medo experimentado por esses adultos, não só interfere na forma como as crianças em processo de desenvolvimento vivenciam essa experiência, como é fruto daquilo que os adultos experimentaram na primeira fase de seu próprio processo de desenvolvimento? Ainda que o conjunto dos autores listados nesse parágrafo não faça nenhuma referência explícita ao imaginário ou à psicanálise, julgamos que a construção de narrativas que apelam aos sentimentos, aos afetos, às sensações, funciona como difusora da ideologia dominante ${ }^{4}$, cristalizando determinadas representações de mundo.

Ao compreendermos o processo descrito, tanto por Vygotsky quanto por Bakhtin, como a interferência da cultura no processo de desenvolvimento humano, nos interrogamos sobre como as narrativas produzidas pelos meios atrairiam a atenção de uma diversidade tão grande quanto à apresentada pela raça humana. Nessa direção,

\footnotetext{
$4 \quad$ Este norte já está presente em Borges $(2009 ; 2010)$. A perspectiva é a de que a formação do imaginário orienta a produção cultural. Isto é, como uma dada ideologia torna-se dominante a partir do papel desempenhado pelos meios de comunicação de massa.
} 
especialmente por nos interessar as conexões estabelecidas entre as informações produzidas pelos meios e sujeitos sociais, parece proveitosa a noção de protocolo de leitura como uma possibilidade concreta de estabelecimento de uma forma média de responder aos estímulos produzidos pelos meios de comunicação. Assim, os protocolos de leitura ${ }^{5}$ representam uma senda aberta nesse processo de compartilhamento de um dado saber no contexto da sociedade. Na verdade, os veículos de informação construiriam, a partir de determinados mecanismos de produção das narrativas, uma aproximação entre a experiência humana e a contada nas páginas dos periódicos - ou seja, entre a realidade e a ficcionalidade.

Partindo dessa perspectiva, é relevante observar como o apelo às sensações e aos sentimentos tem sido, pelo menos ao longo do século XX, uma importantíssima estratégia de interlocução entre os meios e sociedade. Assim, os protocolos de leitura funcionariam como chaves de leitura (mais ou menos homogêneas) entre a narrativa jornalística e a sua leitura, sem perdermos de vista que tal narrativa se assenta sobre a verossimilhança, isto é, aquilo que tem potência de verdade. Portanto, os relatos produzidos pelos veículos de comunicação são concebidos para que o leitor empregue o sentido sobre eles, no entanto os protocolos fornecem as chaves para que tais sentidos sejam empregados de forma mais ou menos semelhantes - o medo, nesse processo, se revela um importante dispositivo de construção dessa interlocução. A essa forma mais ou menos semelhante de compartilhamento de sentidos, avaliamos que o instrumental da psicanálise se revela oportuno. A psicanálise, nessa proposta metodológica, é tomada não na direção da análise clínica, mas como instrumental de análise social, uma vez que entendemos que aquilo que é recalcado no inconsciente é fruto da própria dinâmica da

\footnotetext{
5 Estamos partindo da proposta teórica de Chartier (1996) para quem os protocolos de leitura representam "senhas, explicitas ou implícitas, que um autor inscreve em sua obra a fim de produzir uma leitura correta dela, ou seja, aquela que estará de acordo com sua intenção. Essas instruções, dirigidas claramente ou impostas inconscientemente ao leitor, visam definir o que deve ser uma relação correta com o texto e impor seu sentido" (p. 95). Será a partir dessa concepção que Véron (1981) proporá a de Contrato de Leitura para analisar os textos midiáticos a partir da relação que se estabelece do texto com o receptor. Diante da homogeneização dos conteúdos e dos suportes impressos, baseando-se na teoria da enunciação, o semiólogo argentino se deterá sobre o que diferencia um suporte dos seus concorrentes, ou seja, "as modalidades do dizer". Ainda que não possamos prescindir da noção de Contrato de Leitura, optamos por trabalhar com a de Protocolos de Leitura em função do direcionamento não ser produzido sempre de forma consciente.
} 
sociedade - como é o caso, por exemplo, da associação do medo com o duplo criminalidade-pobreza. ${ }^{6}$

O atravessamento de afetos, emoções, sensações nas construções narrativas

Georg Simmel (1978), a partir da constatação de que a metrópole produziu transformação da vida mental, observa que "os problemas mais graves da vida moderna derivam da reivindicação que faz o indivíduo de preservar a autonomia $\mathrm{e}$ individualidade de sua existência em face das esmagadoras forças sociais, da herança histórica, da cultura externa e da técnica de vida" (1978, p. 11). Ou seja, como pode o indivíduo se mover nessa cidade que muda os fundamentos sensoriais da vida psíquica, a cidade moderna? Para o autor, a cidade moderna é uma cidade hiperestimulante, o que acabará interferindo na forma como as pessoas sentem a cidade ao experimentá-la. Como pode então o sujeito se adaptar à vida cosmopolita? Como conviver com esse hiperestímulo? Simmel oferece como resposta o que ele chama de atitude blasé: experimentar sensações fortes para, em seguida, anulá-las, construindo, assim, uma segurança psíquica através da recusa do sensacionalismo.

Tal intensificação das sensações fortes é observada como inerente à modernidade por Ben Singer. Para o autor, "a modernidade (...) foi concebida como um bombardeio de estímulos. Como afirmou Simmel, a modernidade envolveu uma 'intensificação da estimulação nervosa'. A modernidade transformou os fundamentos fisiológicos e psicológicos da experiência subjetiva" (Singer, 2004, p. 116). A aproximação entre esses autores se dá justamente em função da assunção de que, na modernidade, “o ritmo de vida também se tornou mais frenético, acelerado pelas novas formas de transporte rápido, pelos horários prementes do capitalismo moderno e pela velocidade sempre acelerada da linha de montagem" (Idem). Simmel e Singer vão tomar a modernidade como um conceito neurológico (ou psicológico), na mesma direção de Walter Benjamin. Dessa forma, o que percebe-se é ao caráter singular da modernidade para a

\footnotetext{
6 Ao assumirmos que o imaginário se constrói a partir de um jogo dinâmico entre memória e representação, a construção da memória parece caminhar lado a lado com o projeto que se quer estabelecer. No Brasil, na passagem do século XIX para o XX, foi posto em desenvolvimento um projeto de nação capitaneado pela burguesia. Nesse sentido, a forma como o antagonismo social foi memorizado (ouvido, pela polifonia bakhtiniana, ou apreendido, nos termos vygotskyano) tem produzido efeitos na conformação da nossa sociedade, especialmente a partir da forma como os fenômenos sociais são narrados.
} 
história da humanidade, especialmente a partir das relações que se estabelecem no âmbito da cognição.

A ideia de que a modernidade é hiperestimulante é particularmente importante. Como destaca o autor, "revistas cômicas e jornais sensacionalistas observaram de perto o caos do ambiente moderno com um alarmismo dispótico que, em graus variáveis, caracterizou muito do discurso do período sobre a vida moderna" (Singer, Op. cit., 119, grifos nossos). Na mesma direção, é significativa à remissão à Benjamin no que diz respeito ao fato de "que medo, repulsa e horror eram emoções que a multidão da cidade grande despertava naqueles que a observavam pela primeira vez" (Idem, grifos nossos). O sensacional que aparecia nas publicações da época dava conta das transformações produzidas por uma modernidade que desequilibrava e desestabilizava a época precedente. Singer destaca várias publicações que demonstravam uma predileção por imagens de “'instantâneos” de mortes de pedestres, que ressaltava a ideia de uma esfera pública alterada, definida pelo acaso, pelo perigo e por impressões chocantes mais do que por qualquer concepção (...) de segurança, continuidade e destino autocontrolado" (Idem, p. 126). Cremos que Singer consegue capturar o fluxo do sensacionalismo como processo ${ }^{7}$ quando aponta que

Os retratos da modernidade urbana na imprensa ilustrada parecem flutuar entre uma nostalgia antimoderna de uma época mais tranquila, de um lado, e uma fascinação básica pelo horrível, pelo grotesco e pelo extremo, de outro. As imagens da imprensa ilustrada eram, paradoxalmente, uma forma de crítica social e, ao mesmo tempo, uma forma de sensacionalismo comercializado, uma parte do fenômeno do hiperestímulo moderno que as imagens criticavam (Idem, p. 132-3).

Uma das características dessa conformação social é a concorrência de práticas de leitura pré-modernas com as modernas. Em Carlo Ginzburg (1987), por exemplo, observa-se a presença da circularidade e da oralidade na Europa pré-industrial, através da identificação de "uma cultura oral que era patrimônio (...) de um vasto segmento da sociedade do século XVI", que evidenciava uma circularidade "entre a cultura das classes dominantes e a das classes dominadas, existindo um relacionamento circular feito de influências recíprocas, que se movia de cima para baixo como de baixo para cima" (Idem, p. 12). A presença de Bakhtin em Ginzburg é fundamental. Se há uma

\footnotetext{
Mesmo admitindo que a modernidade inaugura outras práticas de leitura, julgamos que estas não vão eliminar as precedentes. Entretanto, não podemos negar o quanto a circulação maciça de jornais, bem como o recurso a um sensacionalismo grotesco que vendia jornais, representava os reflexos de uma sociedade hiperestimulante.
} 
clara ruptura entre o período pré-moderno e o moderno essa se dá com as propostas universalistas do Romantismo onde, depois dele,

A partir da segunda metade do século XIX, o interesse pelo grotesco diminui notavelmente, tanto na literatura como na história literária. Quando se faz alusão a ele, é para relegá-lo às formas do cômico vulgar de baixa categoria, ou para interpretá-lo como uma forma particular de sátira, orientada contra fenômenos individuais, puramente negativos. Dessa maneira, toda a profundidade, todo o universalismo das imagens grotescas desaparece para sempre (Bakhtin, 1993, p. 39).

Mas, se é verdade que os Românticos relegaram ao grotesco o papel de vida inferior, esvaziando-o da sua função libertadora, de sua função ambivalente, não é menos verdade que o realismo grotesco foi o cimento sobre o qual os jornais do século XIX atraíram seus leitores. Isso nos permite inferir que, mesmo durante o processo de construção da modernidade, a circularidade se fazia presente. Nos periódicos do século XIX, tal como aponta Singer, algumas formas de expressão do mundo popular vão estar presentes através do emprego da linguagem de suas formas e símbolos. Outra característica que merece destaque é que o rebaixamento - outro traço marcante do realismo grotesco - também estava presente nas construções discursivas modernas, transferindo ao plano material o que era elevado, ideal e abstrato. Entretanto, não é só através da oralidade que a circularidade se fazia presente no contexto da modernidade. Em Chartier (2004), observa-se que, desde o século XVI, os textos e os livros eram destinados a uma civilidade, ocupando o impresso um papel significativo na circulação dos modelos culturais, indicando que existiam outras formas de apropriação desse tipo de leitura por leitores populares. Se tomarmos a educação no Antigo Regime, por exemplo, podemos perceber, através de Chartier, a aproximação dos mercadores com a nobreza pelo fato de seus filhos estudarem juntos ${ }^{8}$. Nesse cenário, a leitura em voz alta é uma das formas de mediação presente na configuração social. Nestes termos, nos parece plausível pensar que, a partir de reconfigurações de matrizes da cultura popular na modernidade, já estaríamos diante de uma estratégia que atualizaria (e ganharia materialidade na imprensa) dispositivos narrativos arraigados na tradição.

Em Martin-Barbero, encontramos uma fecunda análise do jogo que se estabelece a partir da modernidade. Se é ilusória a distinção entre alta e baixa cultura, é necessário que se desenvolva uma série de estratégias de conformação do que pertenceria a um

8 Situação análoga é a de Menocchio em O queijo e os vermes, onde Ginzburg mostra como o moleiro se apropriava dos conteúdos discursivos que circulavam no Antigo Regime. 
campo ou ao outro. É nesse ambiente que o excesso e a contenção emergiram como parâmetros de classificação entre os níveis de cultura. Esse é o contexto em que se associa o melodrama, sobretudo em função do seu caráter excessivo e da sua relação com o carnavalizado, a um gosto estritamente popular. Vejamos algumas características fundamentais do melodrama tomadas a partir de Barbero, mas também de Baltar (2006): excesso; identificação/projeção (catarse); justiça; dramatização; música; fatalismo; esquematização maniqueísta; hibridização de gêneros; emoticidade (sensações), em oposição à razão; estrutura sintática/gramática própria; presença de mitos, arquétipos, estereótipos, oposição público versus privado; pedagogia moral. O melodrama, pela forma teatral, pela forma dramatúrgica que o compõe no século XIX, vai ser identificado como o espetáculo popular; ele representaria um lugar de chegada de uma memória narrativa e gestual e lugar de emergência de uma cena de massa. Tais características do melodrama aparecem refletidas na estrutura destacada por Barbero (Op. cit., p. 174):

\begin{tabular}{|c|c|c|c|}
\hline $\begin{array}{c}\text { 4 } \\
\text { sentimentos }\end{array}$ & $\begin{array}{c}\text { 4 situações } \\
\text { /sensações }\end{array}$ & personagens & 4 gêneros \\
\hline Medo & Terríveis & Traidor & Romance \\
& & & de ação \\
\hline Entusiasm & Excitantes & Justiceiro & Epopéia \\
o & Ternas & & Tragédia \\
\hline Dor & Burlescas & Bobo & Comédia \\
\hline Riso & &
\end{tabular}

Em nossa avaliação, essas matrizes estarão presentes na produção discursiva da imprensa, não só na passagem do século XIX para o XX, como contemporaneamente. No entanto, são o folhetim e o fait-divers os principais responsáveis pelo processo de massificação dos jornais. Nesse sentido, nos parece plausível a hipótese de que a imprensa possa - a partir de um amálgama produzido dentro das páginas dos periódicos entre a encenação melodramática e a noção de medo, por exemplo - influenciar decisivamente na construção de um imaginário acerca dos lugares sociais da elite e do povo. Dentro dessa ótica, trabalho interessante é o de Meyer (1996) para quem o folhetim passou por transformações que redundaram no seu caráter pedagógico. Para a autora, o folhetim pertence ao mesmo campo semântico do melodramático, do folhetinesco, do sentimentalismo, das lágrimas, das "emoções baratas", dos suspenses e 
reviravoltas, da linguagem retórica e chapada, com personagens e situações estereotipadas que marcam os gêneros populares do século XIX e que apareceram atualizados no Rocambolesco ${ }^{9}$. Da ascensão do gênero, com Eugéne Sue e Alexandre Dumas, passando pelo Rocambole, até a sua fase realista, é oportuno destacarmos o quanto o folhetim servirá à moral burguesa como um projeto moral e pedagógico.

Não queremos causar a falsa impressão de que a burguesia proporciona essa transformação do folhetim com vistas à implantação de um projeto de sociedade. Mas, não é menos verdade que, uma vez aumentada a popularização do gênero, a burguesia se serve dele como um poderoso difusor de suas concepções. Esse é o contexto onde, na Europa, assiste-se a uma série de transformações em função do processo de industrialização e das inovações tecnológicas. É um momento histórico onde, frente a essas novidades, o ambiente urbano vai se dividir entre prazer/projeção e medo/repugnância. A questão da alteridade, da preocupação com o Outro vai estar no centro da ambiguidade que marca a aparente oposição racional versus emocional. Será no século XIX que a sensação, a emoção, o sentimento, comporão o corolário do qual emergirá a "literatura de sensibilidade", literatura essa onde as reapropriações e mestiçagens de outros gêneros ocorrem. ${ }^{10}$ Assim, essas matrizes reconfiguradas, a partir do século XIX, vão se assentar nessa tensão entre uma resposta física e uma resposta psíquica frente ao novo. Uma questão que parece ser central é a questão da alteridade: temos medo, mas ainda assim desejamos o outro ${ }^{11}$. Um Outro que, principalmente a partir desse momento histórico, tem classe social, gênero, localização geográfica etc.

\section{O medo reificado no imaginário social}

O apelo às sensações nos parece um dispositivo narrativo de longuíssima duração. Esse, inclusive, é o sentido de Borges (2009) propor o deslocamento da noção de imprensa sensacionalista para a de narrativa sensacionalista. Esta seria uma estratégia

\footnotetext{
9 Tal gênero, como destaca Meyer, se caracterizaria pela presença de aventuras extraordinárias, exageradas, extravagantes, com enredos cheios de peripécias, complicações, esquemas, inverossímeis. Tal alusão explicita uma relação direta à Rocambole, protagonista central do escritor francês Pierre-Alexis Ponson du Terrail, que forneceu à imprensa folhetins com tais características.

10 Ainda que no Brasil tais transformações tenham ocorrido no final do século XIX, julgamos que o processo desenvolvido na Europa serviu como paradigma, especialmente em função da importação de estilos de vida e costumes do Velho continente.

11 Esse Outro (moderno) é emergente do processo de urbanização/modernização.
} 
discursiva que mescla realidade e ficção e permitiria à narrativa jornalística se envolver com os protocolos de leitura do público receptor, mantendo a continuidade do fluxo sensacional. A noção de protocolos de leitura, desse modo, acaba sendo preponderante para nós, uma vez que seria por seu intermédio que a imprensa construiria/reificaria o imaginário social. Embora não compartilhemos da ideia de um público receptor passivo que seja manipulado pelos meios de comunicação, não é menos explícito que os leitores, ao lerem uma informação, se apropriam dela de forma mais ou menos semelhante. Isso se torna possível a partir de uma perspectiva aberta pela noção de protocolos de leitura, que funcionariam a partir de uma espécie de saber compartilhado, que estamos compreendendo como imaginário. Afinal, nos parece plausível aceitar a perspectiva de que as referências simbólicas da cultura popular serviram de base para a difusão de um tipo de narrativa que dissemina um conteúdo político, evidenciando-se a relação entre imaginário e projeto político.

Quando se debruça sobre os anos 1920, Barbosa (2007) destaca a interconexão entre a verossimilhança e as sensações presentes nas páginas dos jornais. Tal dado nos permite perceber que, até o final dos anos 1940, não havia a distinção produzida pelo jornalismo americano entre uma imprensa dita séria e uma sensacionalista. $\mathrm{Na}$ verdade, era muito comum o apelo às sensações nos periódicos brasileiros. A autora nos mostra que "a marca mais inflexiva da imprensa carioca no final dos anos 1920 é o destaque que os jornais dão às notas sensacionais, que falam dos dramas quotidianos envolvendo crimes, violência, desfechos trágicos de toda a natureza” (p. 60). Dessa forma, o apelo às sensações refletia uma clara estratégia de aumento de circulação dos jornais, sem que houvesse uma preocupação em se reservar um espaço para os chamados juízos de fato e outro para os de valor. Pois, se havia uma clara estratégia, por parte dos donos de jornais, de aumentar a circulação dos diários, não é menos claro que acompanhava esse aumento uma tentativa de controle da forma como esses leitores deveriam se apropriar da informação. Mas, para além dessa construção fantasiosa do real, era necessário que esses simulacros fossem captados mais ou menos da mesma forma por um conjunto social bem diversificado.

Em Páginas de Sensação, El Far (2004) aponta como o processo de massificação da literatura, associado à certa ideia de gosto popular, se desenvolve no Rio de Janeiro. Um dos pontos que é oportuno mencionarmos é que "gosto popular" funcionava como 
uma espécie que rubrica que abarcaria um tratamento editorial com baixo custo de produção direcionado às pessoas alfabetizadas. Evidentemente, isso permitia que aquelas obras fossem compartilhadas por um contingente que não se restringia às elites. Outro aspecto interessante é como o Rio de Janeiro funcionou como centro irradiador de uma cultura dos impressos, uma vez que a maior parte da população alfabetizada se concentrava na Capital Federal. Esse é um elemento essencial para entendermos a especificidade da cidade do Rio de Janeiro no contexto brasileiro. Pois, para nós, provém desse contexto a importância simbólica que a cidade carioca ainda ocupa no imaginário social. Ao abordar a especificidade do romance de "sensações”, El Far alerta que, "apesar de apresentarem um estilo literário próprio, em geral, eram editores e jornalistas os responsáveis pela divulgação de romances nos periódicos da época, que avisavam ao público sobre o caráter 'sensacional de determinada obra” (p. 113).

Tal como em Barbosa, El Far aponta para a presença de um repositório que deveria orientar um determinado tipo de leitura a partir do material produzido. Nesse sentido, julgamos novamente que tanto uma autora quanto a outra estariam a indicar a presença de um imaginário que teria como referência as tradições, por um lado, e o projeto político, por outro. Assim se pronuncia El Far, ao falar das sensações:

A recorrência desse termo, em inúmeros outros textos, evidenciava a
existência de uma compreensão comum acerca do seu significado,
como também a predileção por assuntos ou situações capazes de
envolver sentimentos pouco conhecidos na ordem do cotidiano. Se as
regras da lei, da moral e dos bons costumes impediam que ações de
grande emoção pudessem ser praticadas sem o temor das
consequências futuras, a história contada, ao penetrar na imaginação
do leitor ou de seu ouvinte, fornecia a possibilidade de aproximação
com uma realidade que, apesar de distante, poderia ser extremamente
interessante. Anexando à narrativa cores, sons, cheiros e ritmos de sua
predileção, o homem de finais do século XIX criava acesso a uma
gama infinita de percepções extraordinárias (Idem, p. 119, grifos
nossos).

Um dos nossos principais parâmetros de investigação é que houve um deslocamento da luta ideológica, especialmente por entendermos que, na contemporaneidade, os meios de informação têm sido mais do que meros difusores da produção material da cultura, sendo antes um poderoso agente no antagonismo social sobre a qual a sociedade brasileira se erigiu. Nesse sentido, o que advogamos é que o antagonismo social passou a ser travado dentro do espaço midiático, buscando identificar os sinais que podem nos revelar que o espaço publidiático se constitui como 
um lugar privilegiado para assistirmos àquilo que Zizek (1996a) definiu como "presença da ideologia justamente no lugar onde se julga que ela não esteja”. Quando trabalhamos com a perspectiva de a imprensa, a partir da veiculação de um discurso próprio, interferir decisivamente no jogo de disputas entre as classes, é porque entendemos que a produção discursiva gerada por ela - uma narrativa que torna o medo um sentimento quase concreto - produz, como um de seus efeitos, a construção/reificação de um imaginário social que orienta as ações engendradas por outros atores sociais. Esse tipo de construção semântica revela, dentre outros aspectos, o lugar de produção e enquadramento da memória coletiva - sem que nos esqueçamos do esquecimento igualmente produzido - que converte a imprensa, não naquele partido orgânico do qual já abordou Gramsci, mas na sociedade civil, à medida que pasteuriza os discursos sociais dentro dela. Assim, os jornais se revelam espaços privilegiados para percebermos como essa relação entre razão e sensação aparece através das pistas, das marcas, dos sintomas revelados em suas páginas, oferecendo à sociedade alternativas para que ela enfrente seus medos.

\section{Referências bibliográficas}

BAKHTIN, Mikhail. A Cultura Popular na Idade Média e no Renascimento. Brasília: Ed. da UNB, 1993.

BALTAR, Mariana. "Moral deslizante. Releituras da matriz melodramática em três movimentos". In: Anais do XV COMPÓS. Bauru, 2006.

BARBOSA, Marialva. História cultural da imprensa: Brasil, 1900-2000. Rio de Janeiro: MauadX, 2007.

BORGES, Wilson Couto. "Espaço Publidiático e hegemonia ideológica: construção narrativa atravessada pelo imaginário". In: Passagens - Revista Internacional de História Política e Cultura Jurídica, v.02. Rio de Janeiro, 2010.

Narrativas jornalísticas como produção material da cultura: a presença do imaginário na construção ideológica em torno da criminalidade. Niterói: Tese de doutorado em Comunicação (UFF), 2009.

Criminalidade no Rio de Janeiro: a imprensa e a (in)formação da realidade. Rio de Janeiro: Revan, 2006.

FREUD, Sigmund. "Totem e tabu. In: Edição Eletrônica Brasileira das Obras Completas, Volume XIII. Rio de Janeiro: Imago, 1998. 
"Mal-estar na civilização". In: Edição Eletrônica Brasileira das Obras Completas,

Volume XXI. Rio de Janeiro: Imago, 1998.

EL FAR, Alessandra. Páginas de sensação. Literatura popular e pornográfica no Rio de Janeiro (1870-1924). São Paulo: Cia. das Letras, 2004.

GINZBURG, Carlo. Mitos, Emblemas e Sinais. São Paulo: Cia. das Letras, 1989.

O queijo e os vermes: o cotidiano e as idéias de um moleiro perseguido pela inquisição. São Paulo: Cia. das Letras, 1987.

HOUAISS, Antônio. Dicionário Eletrônico Houaiss da língua portuguesa. Rio de Janeiro: Objetiva, 2009 (CD-rom).

LACAN, Jacques. Escritos. Rio de Janeiro: Jorge Zahar Editor, 1998.

"O estádio do espelho como formador da função do eu". In: ZIZEK, Slajov (Org.). Um Mapa da Ideologia. Rio de Janeiro: Contraponto, 1996.

Seminário 22: Real, Simbólico, Imaginário. Inédito (CDROM - Obra de Jacques Lacan \{Sólo Lectura\}), 1975.

MARTÍN-BARBERO, Jesús. Dos meios às mediações: comunicação, cultura e hegemonia. Rio de Janeiro: Editora UFRJ, 2001.

MEYER, Marlyse. Folhetim: uma história. São Paulo: Cia. das Letras, 1996.

MESQUITA, Mário. “A personagem jornalística - da Narratologia à Deontologia” In: MIRANDA, José A. B. de; SILVEIRA, Joel F. da. As Ciências da Comunicação na Viragem do Século. Lisboa: Vega (Comunicação e Linguagens) 2002.

MOSCOVICI, Serge. Representações sociais: investigações em psicologia social. Rio de Janeiro, Vozes, 2003

A Representação Social da Psicanálise. Rio de Janeiro: Zahar Editora, 1978.

MOTTA, Luiz G.; COSTA, Gustavo B.; LIMA, Jorge A. "Notícia e construção de sentidos: análise da narrativa jornalística". IN: Revista Brasileira de Ciências da Comunicação, Vol. XXVI, No. 1. São Paulo, 2005.

OLIVEIRA, Marta Kohl. Vygotsky: aprendizado e desenvolvimento, um processo sóciohistórico. $4^{\text {a }}$ ed. São Paulo: Scipione, 2002.

ROAZZI, Antonio; FEDERICCI, Fabiana C. B.; CARVALHO, Maria do Rosário. "A Questão do Consenso nas Representações Sociais: Um Estudo do Medo Entre Adultos". IN: Psicologia: Teoria e Pesquisa. Maio-Agosto 2002, Vol. 18 n. 2.

SIMMEL, Georg. "A metrópole e a vida mental”. IN: VELHO, Otávio Guilherme (org.). O Fenômeno Urbano. Rio de Janeiro: Zahar Editores, 1978.

SINGER, Ben. "Modernidade, hiperestímulo e o início do sensacionalismo popular". IN: CHARNEY, Leo e SCHWARTZ, Vanessa (orgs.). O cinema e a invenção da vida moderna. São Paulo: Cosac \& Naify, 2004. 
SPINK, Mary Jane. Linguagem e produção de sentidos no cotidiano. Rio de Janeiro: Centro Edelstein de Pesquisas Sociais, 2010.

VYGOTSKY, Lev Semenovich. Pensamento e linguagem. São Paulo: Martins fontes, 1998.

ZIZEK, Slavoj. Um Mapa da Ideologia. Rio de Janeiro: Contraponto, 1996. 